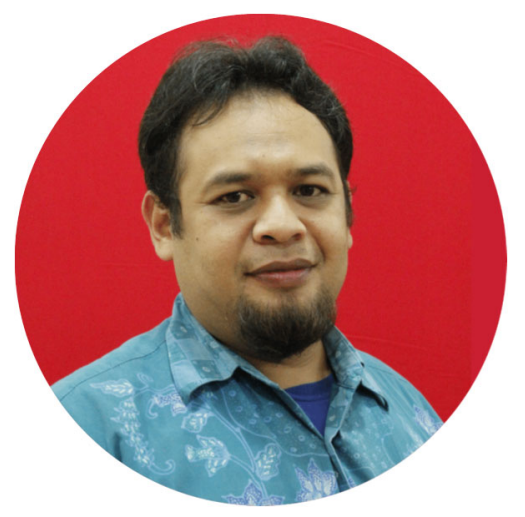

\title{
Welcoming Remarks from the Chairman
}

The honorable Rector of Universitas Gadjah Mada, Prof. Dr. Panut Mulyono.

Dear distinguished guests, invited speakers, and participants.

It is my great pleasure and honor to welcome you to the 6th International Conference on Science and Technology (ICST 2020). This year, the organizing committee of ICST 2020 has come to the difficult decision to hold the conference online. We are making this decision after much consideration of the ongoing spread of COVID-19, striving to take the most socially responsible action while maintaining a forum in which our community can share their work, discovery, and latest research results and exchange their ideas. In addition, direct contacts among the researchers and scientists will therefore promote not only national but also international research networking as well as collaboration in the future.

The ICST 2020 consists of five symposia, namely Computer and Information Technology symposium; Electronics, Power, Communication, Control, and Instrumentation symposium; Life Sciences, Materials, and Applied Chemistry symposium; Mechanical and Industrial Engineering symposium; and Remote Sensing and Geomatics symposium and in conjunction with the 1st Geoscience and Environmental Management symposium.

The conference committee has invited six renowned speakers: Prof. Keisuke Ohto from Saga University, Japan, Prof. Josaphat Tetuko Sri Sumantyo from Chiba University, Japan, Prof. Pitoyo Peter Hartono from Chukyo University, Japan, Dr. Fatwa Firdaus Abdi from Helmholtz Zentrum Berlin, Germany, Dr. Hui Luo from Imperial College London, United Kingdom, and Prof. Nalan Kabay from Ege University, Turkey. This year, the ICST 2020 has received 428 submissions from 20 countries throughout the world. All submitted papers went through a rigorous peer-review process. Based on the results of the review process, 275 papers have been selected, which constitute the acceptance rate of $64 \%$. All accepted and presented papers will be submitted to journals or proceedings that are indexed by Scopus or DOAJ. This conference will not become a reality without support and assistance of many parties. In this occasion, I would like to sincerely thank the Rector of Universitas Gadjah Mada, BPP, DSSDI officers and staffs, and also all invited speakers.

Last but not least, we also wish to thank reviewers for invaluable comments and suggestions and the organizing committee for arranging all needed facilities to the success of this conference.

Yogyakarta, September 7, 2020

Chairman of the Organizing Committee,

Dr.Eng. Ahmad Kusumaatmaja 


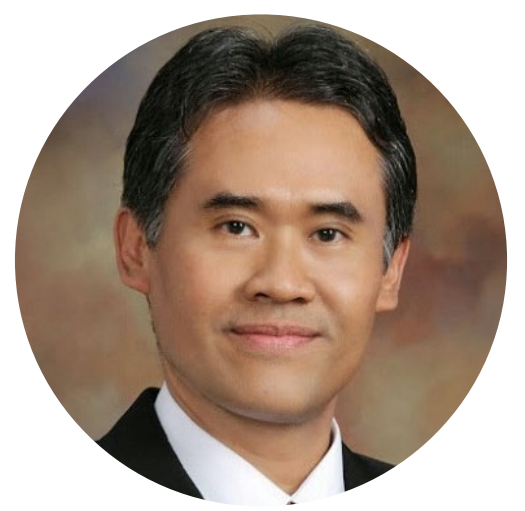

Welcoming Remarks from the Rector of Universitas Gadjah Mada

Dear distinguished invited speakers, participants, ladies and gentlemen,

On behalf of Universitas Gadjah Mada, it is my pleasure and privilege to welcome you to the 6th International Conference on Science and Technology (ICST 2020), hosted by Universitas Gadjah Mada (UGM). In particular, I would like to extend my gratitude to distinguished keynote speaker. First of all, please allow me to express my sincere appreciation for Dr. Hui Luo from Imperial College London, United Kingdom; Prof. Josaphat Tetuko Sri Sumantyo from Chiba University, Japan; and Prof. Keisuke Ohto from Saga University, Japan.

This conference brings together academics and professionals across the whole spectrum of science and technology in a time of exciting technological advancement. As we know, society has never moved faster without the whole acceleration spectrum of science and technology timelines. History of UGM's education has earned a reputation as a pioneering university, pushing the boundaries between academics and professionals across the world, to serve and discover scientific progress as a valuable source of knowledge for the benefit of humankind.

Today, the world is in a pandemic situation, which requires us to adapt to the current situation. The pandemic has changed many habits of human life, but we believe that this situation cannot diminish our intellectual ability to always contribute knowledge to the world. The wonderful thing about ICST is bridging the gap between disciplines through this conference to bring and share their innovation, research, and ideas about our scientific issues today. UGM is proud to be leading the way in facilitating the interdisciplinary research dissemination of cutting-edge information. We are proud to conduct this conference, even though we conduct this conference virtually.

After 5 years, ICST as a part of the Annual Scientific Conference Series holding annual gatherings for the brilliant minds from Indonesia and abroad to share the latest findings in their fields. It proves UGM's consistency to preserve the international academic's relation. This series has been an enormous success to bring collaboration with our international partners, shaping the scientific networks, increasing Indonesia author's greatness in the global publication scopes, and with a global readership, and underscoring UGM's place as a standard-bearer of scientific development. 
We are honored and humbled to many experts who have attended this year's conference. We thank the speakers for the expertise and knowledge that will bring to spur great discussion during the conference. Special thanks are also extended to the organizing committee members for their hard work, as well as the entire staff of UGM's Badan Penerbit dan Publikasi (BPP) for making and bringing the ICST 2020 to life. And finally, we would like to thank all the conference participants who will contribute to making this truly the most memorable ICST yet. For unfinished business, this event should impact the fields of science, technology and also our humanity for the next many years.

I am sure you will have fruitful and rewarding exchanges.

I hope you all enjoy this conference. Thank you.

Rector of Universitas Gadjah Mada,

Prof. Ir. Panut Mulyono, M.Eng., D.Eng. 